\title{
Palavra falada, diálogo e escuta freireanos: contribuições à compreensão dos saberes dos estudantes da EJA
}

\author{
Spoken word, dialogue and listening freirean: contributions to \\ understanding the knowledge of eja students
}

\section{Palabra hablada, diálogo y escuchando freirean: contribuciones a la comprensión del conocimiento de los alumnos de EJA}

Francisco Josimar Ricardo Xavier 1

https://orcid.org/0000-000I-6376-2828

Júlio César de Moura Dias²

https://orcid.org/0000-0002-82/2-0190

Adriano Vargas Freitas ${ }^{3}$

https://orcid.org/0000-0002-4602-3473

Resumo: Neste artigo discutimos sobre como a escuta dos saberes dos jovens, adultos e idosos podem contribuir para os professores construírem práticas curriculares mais próximas das realidades da Educação de Jovens e Adultos (EJA). Nele apresentamos as narrativas de João e Dona Anita, que são analisadas à luz da palavra falada, do diálogo e da escuta atenta freireanos. João apresenta uma matemática ligada aos saberes construídos no trabalho, e outra, ligada à sua vida de estudante. Dona Anita traz uma vida atravessada pelas questões de gênero, e narra ter conhecido as letras no trânsito entre sua casa e o trabalho. Os resultados reiteram a ideia freireana de que esses sujeitos chegam à escola com saberes construídos em suas experiências, não sendo, portanto, caixas vazias ou sujeitos analfabetos. Concluímos reforçando a atualidade do pensamento de Paulo Freire, sobretudo, quanto ao diálogo para a construção de uma educação crítica, democrática e libertadora.

Palavras-chave: Paulo Freire. Educação de Jovens e Adultos. Saberes dos estudantes da EJA.

\footnotetext{
' Doutorando em Educação pelo Programa de Pós-Graduação em Educação da Universidade Federal Fluminense (PPGE-UFF). E-mail: josimar_xavier@id.uff.br

${ }^{2}$ Mestre em Educação pelo Programa de Pós-Graduação em Educação da Universidade Federal Fluminense (PPGE-UFF). Professor de Artes na rede pública municipal de Macaé-RJ. E-mail: juliocmdias 1970@gmail.com

${ }^{3}$ Doutor em Educação Matemática pela Pontifícia Universidade Católica (PUC-SP). Professor do Programa de Pós-Graduação em Educação da Universidade Federal Fluminense (PPGE-UFF). E-mail: adrianovargas@id.uff.br
}

Olhar de professor, Ponta Grossa, v. 24, p. I-22, e-16666.038, 2021.

Disponível em <https://revistas2.uepg.br/index.php/olhardeprofessor> 
Abstract: In this article we discuss how listening to the knowledge of young people, adults and the elderly can help teachers build curricular practices that are closer to the realities of Youth and Adult Education (EJA). We present the narratives of João and Dona Anita. The narratives are analyzed in the light of the spoken word, dialogue and attentive listening to Freireans. João presents a mathematics linked to the knowledge built at work, and another, linked to his student life. Dona Anita presents a life crossed by gender issues, and narrates having known the letters in the traffic between her home and work. The results reiterate the Freirean idea that these subjects arrive at school with knowledge built on their experiences. They are not empty boxes or illiterate subjects. We conclude by reinforcing the actuality of Paulo Freire's thinking, above all, regarding the dialogue for the construction of a critical, democratic and liberating education.

Keywords: Paulo Freire. Youth and Adult Education. Knowledge of EJA students.

Resumen: En este artículo discutimos cómo escuchar los conocimientos de los jóvenes, adultos y ancianos puede ayudar a los docentes a construir prácticas curriz culares más cercanas a la realidad de la Educación de Jóvenes y Adultos (EJA). En él presentamos las narrativas de João y Doña Anita, que se analizan a la luz de la palabra hablada, el diálogo y la escucha atenta de los freireanos. João presenta una matemática ligada al conocimiento construído em el trabajo y otra ligada a su vida estudiantil. Doña Anita trae una vida atravesada por cuestiones de género, y dice que conocía el alfabeto en el tráfico entre su casa y su trabajo. Los resultados reiteran la idea freireana de que estos sujetos llegan a la escuela com conocimientos construidos a partir de sus experiencias Paulo Freire; Educación de jóvenes y adultos; Conocimiento de los estudiantes de EJA.por lo tanto, no son cajás vacías ni sujetos analfabetos. Concluimos reforzando la actualidad del pensamiento de Paulo Freire, sobre todo, sobre el diálogo para la construcción de una educación crítica, democrática y liberadora.

Palabras-clave: Paulo Freire. Educación de jóvenes y adultos. Conocimiento de los estudiantes de EJA.

\section{Introdução}

A educação brasileira é, de uma maneira geral, constituída por movimentos de perdas e ganhos, seja quanto aos direitos sociais, à efetivação de propostas pedagógicas, de políticas públicas ou ações educativas. Esses movimentos são tensionados, sobretudo, pelas forças discursivas disputadas entre representantes do Estado, que imprimiram uma elitização da escolarização, e de representantes de movimentos sociais que vêm, desde tempos remotos, fazendo frente na luta pelos direitos dos menos favorecidos economicamente ascenderem à escola (GONDRA; SCHUELER, 2008).

Esse embate de tensões vai ganhando força à medida que intelectuais assumem posturas políticas em defesa de uma educação pública, laica e de qualidade para todos os brasileiros. Dentre estes, destacamos Paulo Freire que, acompanhado de outros intelectuais de seu tempo, propõe um sentido de educação visando à conscientização crítica dos sujeitos das classes populares, com a finalidade de estes contribuírem para o desenvolvimento nacional que fora pensado para o Brasil da segunda metade do século XX. Contudo, o contexto político configurado em meados dos anos 1960 fixa a ditadura militar como regime de governo no país, instalando-a até meados dos anos 1980 , ocasionando, entre outros efeitos, a exclusão das ideias freireanas de educação como ideal de política nacional.

Essa exclusão, ainda que tenha objetivado silenciar as ideias freireanas, não o consegue em sua totalidade. No âmbito de alguns movimentos sociais religiosos, movimentos de educação popular e de associações comunitárias, tais ideias resistiram e continuaram aflorando o sentido de educação como

Olhar de professor, Ponta Grossa, v. 24, p. I-22, e-16666.038, 2021.

Disponível em <https://revistas2.uepg.br/index.php/olhardeprofessor> 
conscientizadora crítica e como ação para a libertação dos sujeitos das classes populares de situações de opressão. Essa resistência contribuiu para que várias pesquisas fossem realizadas, tanto no sentido de demarcar o legado de Paulo Freire na educação brasileira, como no de compreender como ocorrem os processos de alfabetização de sujeitos das classes populares, de compreender as desigualdades sociais no Brasil, dentre outros aspectos.

O artigo ora apresentado visa endossar o legado de Paulo Freire na educação brasileira, com destaque à especificidade da contribuição deste intelectual à educação voltada para pessoas jovens, adultas e idosas. Ele foi construído por meio de diálogos estabelecidos entre pesquisas ${ }^{4}$ desenvolvidas no interior do Grupo de Pesquisa em Educação de Jovens e Adultos (GPEJA), do Programa de PósGraduação em Educação da Universidade Federal Fluminense (UFF).

Tais pesquisas têm em comum as ideias freireanas de educação como referencial, e tiveram como foco central discussões envolvendo a construção dos saberes dos estudantes da modalidade Educação de Jovens e Adultos (EJA) de dois municípios brasileiros, um da Região Nordeste e outro da Região Sudeste. A aproximação estabelecida entre as pesquisas constituiu-se da reflexão de que os sentidos de palavra falada, diálogo e escuta atenta, na perspectiva freireana, possibilitam aprofundamentos da compreensão de como os saberes dos jovens, adultos e idosos, estudantes da EJA, são construídos em suas experiências de estar com o e no mundo.

Com este artigo objetivamos discutir sobre como a escuta atenta dos saberes dos estudantes da EJA, entendidos à luz da palavra falada e do diálogo freireanos, podem contribuir para que os professores construam práticas curriculares mais próximas das realidades dos educandos. Com isso, endossamos a atualidade do pensamento de Paulo Freire nas discussões sobre as desigualdades sociais, principalmente, no que diz respeito ao acesso à escolarização no Brasil atual.

Optamos por iniciar o artigo destacando como as ideias freireanas atravessam a educação brasileira e a sua história. Em seguida, encaminhamos nossas perspectivas sobre como a escuta atenta dos saberes dos estudantes da EJA podem contribuir para as práticas curriculares docentes. Posteriormente, trazemos a escuta dos saberes matemáticos de João e a escuta dos saberes da leitura da palavra escrita e a leitura de mundo das experiências de Dona Anita ${ }^{5}$.

\footnotetext{
${ }^{4}$ As pesquisas foram realizadas em nível de Mestrado e uma delas contou com financiamento da Coordenação de Aperfeiçoamento de Pessoal de Nível Superior (CAPES).

${ }^{5}$ João e Dona Anita são nomes fictícios.
}

Olhar de professor, Ponta Grossa, v. 24, p. I-22, e-16666.038, 202 I.

Disponível em <https://revistas2.uepg.br/index.php/olhardeprofessor> 
Palavra falada, diálogo e escuta freireanos: contribuições à compreensão dos saberes...

\section{As ideias freireanas na educação brasileira}

Na segunda metade do século $X X$, ○ Brasil viu surgir importantes movimentos populares ${ }^{6}$ preocupados com a identidade nacional. Em paralelo, diversos segmentos da sociedade se mobilizaram para a discussão de necessárias mudanças de paradigmas educacionais como forma de enfrentar problemas vivenciados nessa área. Surgem os "Centros Populares de Cultura", os "Movimentos de Cultura Popular", entre outras organizações que objetivavam a transformação das estruturas sociais vigentes e a valorização da autêntica cultura nacional, por considerar que a educação brasileira deveria estar centrada na própria cultura do seu povo. Todos esses movimentos, de acordo com Saviani (2007), serviram de base às ideias de uma educação crítica e libertadora que estavam sendo desenvolvidas na época por Paulo Freire.

Novos princípios orientadores para a revisão das ideias pedagógicas relacionadas ao trabalho educacional com jovens e adultos passaram a ser defendidos por Paulo Freire, tais como o entendimento de que o analfabetismo é uma consequência da exclusão social, econômica e cultural, e que é necessário buscar entender o estudante adulto em suas especificidades, proporcionando atividades pedagógicas em um currículo escolar com especial atenção à valorização dos saberes oriundos de suas experiências de vida.

Sobre a figura e as ideias inovadoras de Paulo Freire, assim nos relata o professor Ernani Maria Fiori apud Freire (2005):

Paulo Freire é um pensador comprometido com a vida: não pensa ideias, pensa a
existência. É também educador: existência seu pensamento numa pedagogia em
que o esforço totalizador da "práxis" humana busca, na interioridade desta,
retotalizar-se como "prática da liberdade". Em sociedades cuja dinâmica
estrutural conduz à dominação de consciência, "a pedagogia dominante é a
pedagogia das classes dominantes". (...) Nessas sociedades, governadas pelos
interesses de grupos, classes e nações dominantes, a "educação como prática da
liberdade" postula, necessariamente, uma "pedagogia do oprimido". Não
pedagogia para ele, mas dele. Os caminhos da liberação são os do oprimido que
se libera: ele não é coisa que se resgata, é sujeito que se deve autoconfigurar
responsavelmente (FREIRE, 2005, p. 7).

A experiência e o êxito de Paulo Freire na alfabetização de adultos lhe abrem as portas para o convite a fim de assumir a coordenação nacional do Plano Nacional de Alfabetização, em 1963, apresentando um revolucionário modelo educacional: a pedagogia do oprimido.

Quem melhor que os oprimidos, se encontrará preparado para entender o significado terrível de uma sociedade opressora? Quem sentirá, melhor que eles os efeitos da opressão? Quem, mais que eles, para ir compreendendo a

\footnotetext{
${ }^{6}$ A título de exemplificação, destacamos: Centros Populares de Cultura (1961), Movimento de Cultura Popular (1960) e Mobilização Nacional de Erradicação do Analfabetismo (1958 a 1963).
}

Olhar de professor, Ponta Grossa, v. 24, p. I-22, e-16666.038, 2021.

Disponível em <https://revistas2.uepg.br/index.php/olhardeprofessor> 
necessidade da libertação? Libertação a que não chegarão pelo acaso, mas pela práxis de sua busca; pelo conhecimento e reconhecimento da necessidade de lutar por ela. Luta que, pela finalidade que lhe derem os oprimidos, será um ato de amor, com o qual se oporão ao desamor contido na violência dos opressores, até mesmo quando esta se revista da falsa generosidade referida (FREIRE, 2005, p. 34).

Entretanto, no ano de 1964, um golpe militar obriga Paulo Freire a abdicar desse cargo de coordenador e interrompe a "onda" desenvolvida em torno da busca por uma educação popular, crítica, democrática e libertadora. Nesse momento, os movimentos populares passaram a ser considerados como subversivos e contrários à ordem estabelecida por esse regime, e sofreram dura repressão. Nesta mesma época, são implementadas reformas educacionais que visavam atrelar o modelo educacional brasileiro ao norte-americano, que serviram para os objetivos de formação do cidadão "disciplinado". Segundo Aranha (1989), de uma forma geral, o resultado de tais reformas foi a formação de mão-de-obra barata e meros executantes.

\begin{abstract}
O golpe militar de 1964 opta pelo aproveitamento do capital estrangeiro e liquida de vez o nacional-desenvolvimentismo. (...) Com o êxodo rural, as grandes cidades não têm condições de acolher a todos decentemente. Surgem, então, sérios problemas decorrentes da situação de empobrecimento, que chega a níveis de miserabilidade. (...) Os reflexos imediatos sobre a educação se referem à reestruturação da representação estudantil. Desde o início, a ditadura colocara fora da lei as organizações consideradas subversivas como a UNE (União Nacional dos Estudantes), (...) É eliminada a representação de âmbito nacional e proibida qualquer tentativa de ação política: "estudante é para estudar; trabalhador é para trabalhar” (ARANHA, 1989, p. 253).
\end{abstract}

Em 1967, sob o clima da opressão, uma nova Constituição é promulgada, mantendo a educação como um direito de todos e propondo de forma inédita até então a obrigatoriedade da escola ao brasileiro dos 7 aos 14 anos de idade (BRASIL, 1967). Surge a discussão sobre a escolaridade apropriada aos adolescentes e a emergência de outras faixas etárias para incluir o conceito de jovem. Para Cury (BRASIL, 2000), esse conceito será uma referência para o ensino supletivo. Nesse mesmo ano é implementado o Movimento Brasileiro de Alfabetização (MOBRAL), que ainda manteria algumas características do método de alfabetização desenvolvido por Paulo Freire, mas sem a problematização conscientizadora da realidade do educando.

Com a Lei $n^{\circ} 5692 / 1971$, o ensino supletivo passava a receber maior atenção, pois indicava que sua destinação deveria ser a de oferecer escolarização regular para adolescentes e adultos que não tivessem seguido ou concluído seus estudos na idade tida como apropriada, podendo abranger, consequentemente, além do processo de alfabetização, a aprendizagem, a qualificação e a sua atualização. Uma característica inovadora dessa lei seria a criação da possibilidade de os cursos poderem acontecer, inclusive, de forma remota. 
Palavra falada, diálogo e escuta freireanos: contribuições à compreensão dos saberes...

Após os anos de ditadura militar, o Brasil acompanhou a volta gradual da abertura política em meados de 1980, e com ela uma renovação de forças nos movimentos sociais. Nesse contexto, acompanhamos o surgimento de diversas iniciativas direcionadas à alfabetização de jovens e adultos. Era momento propício para uma nova Constituição que fosse mais condizente com tempos de maior liberdade e valorização da dignidade da pessoa humana, incentivando o pluralismo político e buscando a erradicação das desigualdades sociais, ou seja, a promoção da construção de uma "sociedade livre, justa e solidária” (BRASIL, I988, p. 2).

Chegamos então ao momento propício para uma revisão pedagógica que reestruturasse os princípios norteadores da educação nacional. É promulgada a Lei n 9394/1996, que origina a nova Lei de Diretrizes e Bases da Educação Nacional (LDB/96), que transforma em direito do cidadão e dever do Estado antigos anseios de diversos movimentos populares, dentre eles a erradicação do analfabetismo e a universalização do atendimento escolar.

Décadas depois, em nossos dias, nos é possível verificar algumas mudanças na área da educação, mas não suficientes para completar a erradicação do analfabetismo, por exemplo. De acordo com dados da Pesquisa Nacional por Amostra de Domicílios (PNAD) Contínua Educação7, em 2019, a taxa de analfabetismo no Brasil estava em 6,6\%, o que representa cerca de II milhões de pessoas de I5 anos ou mais que, pelos critérios do Instituto Brasileiro de Geografia e Estatística (IBGE), não são capazes de ler e escrever nem ao menos um bilhete simples.

Somamos a este quadro, a ainda constatação de que novos problemas se aliam a outros já antigos em relação aos cursos que são oferecidos a estes indivíduos. Se já há algum tempo a EJA convive com ○ seu gradual desmonte proveniente de práticas de nucleação ${ }^{8}$ de suas escolas, aliadas à implementação da Educação à Distância (EAD), em nossos dias acompanhamos a implementação de currículos homogeneizantes, moldados pela Base Nacional Comum Curricular (BNCC, 2017), que, embora não seja específica para a EJA, tem sido utilizada para processos de "atualização" destes currículos.

Esclarecemos que nos distanciamos do sentido de currículo enquanto grade de conteúdos escolares que visam o engessamento das práticas dos professores, em que entendemos estar configurada a BNCC. Explicitamos que compreendemos a EJA como uma modalidade da educação que contempla jovens, adultos e idosos, com percursos de vida, biografias, aprendizagens e experiências específicas e, portanto, diferentes entre si. Esse sentido de EJA no leva a dialogar com um sentido de

\footnotetext{
${ }^{7}$ Pesquisa divulgada em 15/07/2020. Disponível em https://bit.ly/32wKyU4. Acesso em I6. jul. 2020.

${ }^{8}$ Denominamos de nucleação das escolas, a prática utilizada por diversas redes de ensino municipais e estaduais, em oferecer vagas para os cursos de EJA em algumas poucas escolas centralizadas, como forma de diminuir seus custos.
}

Olhar de professor, Ponta Grossa, v. 24, p. I-22, e-16666.038, 2021.

Disponível em <https://revistas2.uepg.br/index.php/olhardeprofessor> 
Francisco Josimar Ricardo Xavier, Júlio César de Moura Dias e Adriano Vargas Freitas

currículo que defende a pluralidade das culturas e das experiências dos estudantes, com currículos plurais que consideram "as experiências escolares que desdobram em torno do conhecimento, em meios a relações sociais, e que contribuem para a construção das identidades de nossos/as estudantes" (MOREIRA; CANDAU, 2007, p. 18).

Nestas perspectivas, entendemos que, no histórico da educação brasileira, há resquícios das ideias freireanas, que também foram assumidas com o apoio de outros pensadores de seu tempo. Dentre estes resquícios, destacamos a ideia da universalização da escolarização para todos os brasileiros e da necessidade de se pensar uma escolarização que objetivasse a alfabetização de adultos trabalhadores de acordo com suas especificidades identitárias. Contudo, o que vemos é uma degradação do sentido freireano de que a educação é um processo permanente de construção de conhecimentos que visa à conscientização crítica dos homens sobre as suas realidades, e que precisa levar em consideração seus saberes de mundo.

\section{A escuta atenta dos saberes dos estudantes da EJA}

As ideias de Paulo Freire à construção de uma educação crítica, problematizadora e libertadora, pressupõem o homem como sujeito inconcluso, estando este, desde sempre, em processo constante de construir-se a si mesmo em uma realidade (FREIRE, 2005). O caráter de inconclusão reconhece que ele (o homem), sendo sujeito dotado de uma consciência, é, por isto mesmo, formado por uma capacidade de pensar criticamente sobre suas ações, inclusive, a de questionar o seu estar no mundo.

Entendemos que a capacidade de pensar, própria do homem, somada à de ele refletir criticamente sobre o que pensa e sobre suas ações, alicerçam o sentido freireano de educação enquanto processo de "quefazer permanente" (FREIRE, 2005, p. 84) e, ao mesmo tempo, ação que pode constituir-se como prática para a liberdade. Analisamos que esta liberdade refere-se à saída do homem de situações que o referido intelectual chama de "fixismo" e "imobilismo", próprios de uma educação bancária, que pouco contribui para a sua formação e à sua realidade.

Compreendemos que os questionamentos que levam os homens a refletirem sobre si mesmos, a respeito das suas vivências e das suas experiências com o mundo, contribuem para que a liberdade seja tomada também no sentido de saída de situações de opressão. Esta saída é possibilitada, segundo Freire (1999), a partir do momento em que os homens, compreendendo-se inconclusos, passam de um estágio de uma consciência de percepção ingênua para uma consciência de percepção crítica de suas realidades. Esse sentido de liberdade, contudo, só pode ser construído em comunhão entre aqueles que, sentindo-se oprimidos, optam por se rebelarem contra as situações de opressão.

Desta maneira, a prática que baliza uma educação crítica

Olhar de professor, Ponta Grossa, v. 24, p. I-22, e-16666.038, 2021.

Disponível em <https://revistas2.uepg.br/index.php/olhardeprofessor> 
Palavra falada, diálogo e escuta freireanos: contribuições à compreensão dos saberes...

[...] propõe aos homens sua situação como problema. Propõe a eles sua situação como incidência de seu ato cognoscente, através do qual será possível a superação da percepção mágica ou ingênua que dela tenham. A percepção ingênua ou mágica da realidade da qual resultava a postura fatalista cede seu lugar a uma percepção que é capaz de perceber-se. E, porque é capaz de perceber-se enquanto percebe a realidade que lhe parecia em si inexorável, é capaz de objetivá-la (FREIRE, 2005, p. 85).

A educação crítica e problematizadora, como ação de prática para as liberdades dos homens tem a sua essência assentada no diálogo horizontal entre estes. Entretanto, Freire (2005) aponta que as palavras faladas precisam ser autênticas de verdades que sinalizem as realidades concretas desses sujeitos, e ser compreendidas como práxis de ação-reflexão, os seus elementos constitutivos, que estruturam um diálogo autêntico humano.

Para que um diálogo seja autêntico de formação e construção humanas, "ação" e "reflexão" não podem ser compreendidas isoladamente. Freire (2005, p. 90) destaca que:

[...] esgotada a palavra de sua dimensão de ação, sacrificada, automaticamente, a reflexão também se transforma em palavreria, verbalismo, blábláblá. [...] Se, pelo contrário, se enfatiza ou excluzivisa a ação, como o sacrifício da reflexão, a palavra se converte em ativismo.

Assim, entendemos que, na perspectiva freireana, o elemento que mobiliza a concepção de educação é a relação palavra falada-diálogo dos sujeitos. Essa relação é constituída antes, do entendimento de que a palavra falada é práxis. Por conseguinte, a dialogicidade na educação crítica e problematizadora, supõe uma relação dialética em horizontalidade entre os sujeitos aprendentes.

Essas compreensões de palavra falada, diálogo e relação de horizontalidade freireanos, atravessam uma concepção ideal de educação voltada para pessoas jovens, adultas e idosas. Compreendemos que no âmbito dos espaços educacionais, que têm esses sujeitos como estudantes, - exercício de reflexão sobre a práxis das palavras faladas nos diálogos por eles construídos, seria uma possibilidade de melhor compreender suas realidades, suas diferenças e os atravessamentos de suas histórias de vida.

No espaço educativo da EJA é comum os professores reconhecerem que os estudantes apresentam saberes oriundos de suas vivências, em especial, aquelas relacionadas às experiências laborais. Entendemos como importante esse reconhecimento, contudo, isso não implica em uma ação de práxis dos professores em suas práticas curriculares. As aulas são preenchidas por momentos de conversas descontraídas, que permitem um encontro entre os sujeitos aprendentes, entretanto, muitas vezes os saberes dos jovens, adultos e idosos resumem-se como "ponto de partida" para iniciá-las.

Acreditamos que uma escuta atenta das falas dos jovens, adultos e idosos poderia ser um início de compreensão de como se constroem os saberes em suas vivências, e de como eles estabelecem aproximações destes com os saberes escolares. Referimo-nos à escuta atenta aproximando-a do 
sentido freireano de que ouvir a palavra falada do outro é o ato primeiro à construção de um diálogo enquanto fenômeno humano autêntico de práxis (FREIRE, 2005). Entendemos que o diálogo, respeitando a presença de diferentes saberes, que é característico da modalidade, deveria proporcionar aos professores da EJA, uma relação positiva com uma variedade de conhecimentos, permitindo-os construir estratégias pedagógicas diversas considerando-os como parte integrante de suas práticas curriculares, não apenas tomá-los como pontos iniciais de suas aulas.

As narrativas dos estudantes da EJA, apresentadas nas próximas seções, são uma amostra de como os saberes dos jovens, adultos e idosos vão sendo construídos em suas experiências. São saberes calcados em suas realidades concretas, de homens e mulheres concretos, cientes de seus estar no e como o mundo, que deveriam, em nossas perspectivas, ser reconhecidos, valorizados e incorporados às práticas curriculares.

\section{“A gente já diz pro cliente a soma”: os saberes e as matemáticas de João}

João é um jovem estudante das séries finais do Ensino Fundamental na EJA, homem negro, de 30 anos, pai de família, morador da zona rural nordestina, que transita diariamente para o centro de uma cidade, onde trabalha. Em 2018 participou de uma pesquisa que buscou compreender as influências de práticas curriculares matemáticas na EJA sobre as permanências dos estudantes em uma escola pública municipal do estado do Ceará9. Ocasião esta em que foi captada sua narrativa, aqui apresentada em forma de diálogo com um dos pesquisadores.

Em um primeiro momento, antes de ter seu diálogo gravado, João mostrou-se apreensivo, "É a primeira vez que participo de uma pesquisa", disse ele. Aos poucos foi mostrando-se sorridente, mais liberto em suas palavras e gestos, o que permitiu o momento de encontro ser leve e descontraído. $\mathrm{Na}$ narrativa de João é possível perceber como os saberes matemáticos são construídos em sua vivência de trabalhador, que desenvolve a função de pintor automotivo.

Pesquisador: - João, fala um pouco sobre como a Matemática está presente na sua vida.

João: - No meu trabalho, quando a gente vai dar um valor de um carro, pintar a peça de um carro. Um paralama, por exemplo, a gente pinta por cento e vinte reais, uma porta a gente pinta por cento e trinta. A gente já pede os duzentos e cinquenta, a gente já diz pro cliente a soma, ai já é uma Matemática. Por exemplo, a lixa, a gente pega uma, faz ela virar quatro lixa. Corta ela em quatro pedaços igual. A gente usa esses quatro pedaços, que é um pra cada peça do carro. Tem que trabalhar no carro com esses quatro pedaços, que é pra economizar. Na escola é normal, a professora passa os dever, explica. $\mathrm{Na}$ hora eu respondo direitinho, mas depois eu esqueço

\footnotetext{
${ }^{9}$ Nessa pesquisa foram ouvidos outros estudantes da EJA, contudo, para fins deste artigo, trazemos João para ilustrar as potencialidades das narrativas dos jovens, adultos e idosos.
}

Olhar de professor, Ponta Grossa, v. 24, p. I-22, e-16666.038, 2021.

Disponível em <https://revistas2.uepg.br/index.php/olhardeprofessor> 
Palavra falada, diálogo e escuta freireanos: contribuições à compreensão dos saberes...

tudo. Eu respondo assim, as pergunta né. Tipo, a professora faz os dever, as conta, eu respondo, às vezes eu pegava de uma amiga que me ajudava, gente muito boa. Mas só que às vezes tava certo, outras, tava errado, aí a professora me ajudava. Se eu fosse estudar pra uma prova de Matemática, eu estudava, mas na hora da prova dava um brancão em mim. Não sou bom de decorar a Matemática. E assim, tem vez que depois de passar a matéria, a professora passa uma prova pra saber né, quem tá bom, quem aprendeu. Às vezes é fácil, às vezes não. Tem coisa que pra mim é difícil.

A narrativa de João é cheia de sentidos, sentimentos e palavras que representam as realidades de muitos estudantes da EJA. São eles, em sua maioria, trabalhadores durante o dia, e estudantes à noite, mas, sobretudo, são humanos, "jovens e adultos com rosto, com histórias, com cor, trajetórias sócio-étnico-raciais, do campo, da periferia" (ARROYO, 2006, p. 22). Histórias que muitas vezes se confundem com as dos colegas de turma, não por acaso, mas porque, historicamente, esses trabalhadores-estudantes da EJA, e a própria modalidade, estão relegados ao segundo plano das políticas educacionais.

João encaminha uma narrativa recortando sua vida em duas, ou em dois momentos: o primeiro como trabalhador, e o segundo como estudante da EJA. Estes momentos se cruzam e dizem muito de seu lugar de sujeito que, em algum momento de sua vida, teve dificuldades em compreender a Matemática passada nos "dever", a mesma da "matéria" que "a professora passa uma prova pra saber né, quem tá bom, quem aprendeu".

Esse recorte feito pelo estudante aponta-nos à compreensão de que, para ele existe pelo menos duas matemáticas. Uma primeira, que acompanha diariamente o João trabalhador, em que ele precisa conhecer as operações básicas. Isso é percebido na seguinte passagem de sua fala: “[...] Um paralama, por exemplo, a gente pinta por cento e vinte reais, uma porta a gente pinta por cento e trinta. A gente já pede os duzentos e cinquenta, a gente já diz pro cliente a soma, ai já é uma Matemática”. Esta é a mesma Matemática que ele precisa ter ciência de usar com parcimônia os seus materiais de trabalho: "[...] a lixa, a gente pega uma, faz ela virar quatro lixa" pois "tem que trabalhar no carro com esses quatro pedaços, que é pra economizar". A operação divisão é compreendida pelo João trabalhador, ela a realiza facilmente com a lixa. Contudo, a razão que o leva a dividir esse material é, não só a distribuição matematicamente em partes iguais, como espera a Matemática da escola, mas o fato de ter que "economizar".

Em nossas perspectivas, João desenvolve a capacidade de reflexão sobre sua ação de dividir a lixa e, ao mesmo tempo, a autoconsciência sobre as possibilidades que podem lhe gerar, se não praticála. Essa complexidade de pensamento, informa Freire (2005), é exclusiva dos homens, não de todos, mas daqueles dotados de uma consciência crítica de sua realidade. Assim, entendemos que João, ao desenvolver a autoconsciência de suas ações, projeta-se como parte integrante de seu contexto, ele pronuncia o seu estar no mundo.

Olhar de professor, Ponta Grossa, v. 24, p. I-22, e-16666.038, 2021.

Disponível em <https://revistas2.uepg.br/index.php/olhardeprofessor> 
Analisamos que o saber matemático do João pintor automotivo, pode até se aproximar do que é ensinado na escola, entretanto, não se reduz aos conhecimentos trabalhados nela, pois, a extrapola de forma a gerar possibilidades reais de resolução de situações vivenciadas em seu cotidiano. contexto da narrativa de João denota proximidade com sua vivência de trabalhador, onde ele precisa construir estratégias de sobrevivências. Isso ele o faz, por exemplo, dividindo a lixa para economizar. Dividir que é, na escola, uma das operações matemáticas mais difíceis, por apresentar um algoritmo complexo, para que seja compreendida (BRASIL, 2002).

A segunda Matemática seria a da escola que, para João, "é normal". Entendemos que ao dizer "Na escola é normal, a professora passa os dever, explica", possivelmente o estudante esteja sinalizando já conhecê-la, talvez por ter passagem anterior pela escola. Ainda que a conheça, a narrativa do estudante retrata reminiscências da Matemática escolar (FONSECA, 200I) como algo que nos parece ter sido ruim para ele: “Às vezes é fácil, às vezes não. Tem coisa que pra mim é difícil”. Apesar da possibilidade de ser fácil, sua fala nos dá a entender que para ele a disciplina escolar foi e é difícil.

Analisamos que a fala João, sobre os saberes matemáticos passados na escola, diz muito também sobre a prática curricular da sua professora, além de mostrar sua dificuldade em apreender esses saberes. Percebemos isso na seguinte passagem de sua narrativa: "Na hora eu respondo direitinho, mas depois eu esqueço tudo. Eu respondo assim, as pergunta né. Tipo, a professora faz os dever, as conta, eu respondo [...]" e complementa, "Não sou bom de decorar a Matemática".

Esta fala de João nos encaminha ao entendimento que ele devota para si um sentimento de culpa por não ter "aprendido" os saberes escolares, do jeito que a professora passava. Esse sentimento, ou ressentimento, é sinalizado por Fonseca (200I) quando, analisando discursos sobre as reminiscências matemáticas de estudantes da EJA, indica que "os alunos parecem devotar às limitações do próprio aprendiz os percalços no fazer e compreender matemáticos; e a seus esforços individuais a possibilidade de superá-los" (FONSECA, 200I, p. 206). Os esforços individuais podem ser compreendidos quando João nos diz que estudava para uma prova, mas na hora lhe dava um "brancão", e quando informa não ser bom em "decorar a Matemática”. Este último excerto, por sinal, retrata o quanto a Matemática ainda é equivocadamente trabalhada em sala de aula, levando os estudantes a decorarem fórmulas, possivelmente desconexas de suas realidades, até mesmo dos sentidos que estão por trás da construção e desenvolvimento dessas fórmulas.

A leitura dessas falas que direcionaram análises a respeito da disciplina Matemática nos permite recorrer à seguinte passagem de Freire (2005), quando discute sobre os currículos escolares:

Simplesmente, não podemos chegar os operários, urbanos ou camponeses, estes, de modo geral, imersos num contexto colonial, quase umbilicalmente ligados ao mundo da natureza de que se sentem mais parte que transformadores, para, à maneira "bancária”, entregar-lhes "conhecimento" ou impor-lhes um modelo de bom 
Palavra falada, diálogo e escuta freireanos: contribuições à compreensão dos saberes...

homem, contido no programa cujo conteúdo nós mesmos organizamos (FREIRE, 2005, p. 97).

As experiências de João poderiam ser levadas em consideração como parte integrante nas aulas de Matemática na EJA. Contudo, antes estas precisariam ser ouvidas atentamente pela sua professora, e esta docente precisaria estar ciente do quanto o sentido de currículo prescritivo não dá conta das realidades dos estudantes e da própria modalidade.

$\mathrm{Na}$ escuta da narrativa de João é possível encontrar um sujeito com consciência de que possui saberes matemáticos, sua dificuldade estaria, em nosso ver, em ele não reconhecer de que maneiras estes se aproximam dos saberes apresentados na escola. Acreditamos que a sala de aula seria o espaço ideal à essa aproximação, onde, reiteramos, sua professora, respaldada por ações dialógicas, poderia não só reconhecer e valorizar, mas incorporar esses saberes à sua prática curricular.

$\mathrm{Na}$ continuidade do diálogo entre o pesquisador e João, percebemos os traços que marcam esse jovem trabalhador que tem motivações específicas para continuar na escola.

Pesquisador: - Como você se sente sendo estudante da EJA?

João:- Agora eu tô gostando, como é que se diz, agora tá fazendo falta pra mim. Eu tenho que correr atrás do que eu perdi, deixei passar. Agora tá melhor e vai melhorar ainda mais minha vida. Eu sinto melhora na minha vontade de ir pra escola. Quando eu tô no trabalho dá cinco e meia eu já vou logo é me ajeitando pra eu vir pra casa, pra eu tomar meu banho, me ajeitar e ir pra escola. Eu perdi muito tempo, eu tenho 30 anos, era pra mim ter terminado já os estudos. Já tô vendo meu filho passando de mim se eu não voltar para a escola.

Pesquisador:- Você só tem 30 anos, é novo.

João:- Mas é que eu brinquei muito na escola. Era pra tá bem de vida agora.

Pesquisador:- Você o quê?

João:- Eu me danei, sabe, quando era mais novo. Me matriculava, desistia, era expulso da escola. Eu brinquei. Agora tá fazendo falta pra mim. E agora tô no EJA.

Pesquisador:- Compreendo. Mas e agora, como você entende que as aulas na EJA contribuem para sua vida?

João:- Deixa eu ver.... de aprendizagem mesmo. Eu vou aprender coisas que tinha que aprender no passado, como também a Matemática. Pode ser que na minha cabeça agora entre alguma coisa.

Pesquisador: - E o que motiva você a estar na sala de aula de EJA?

João:- $O$ que me motiva é que eu quero um emprego melhor pra mim. Quero mudar de profissão, que essa que eu tenho tá causando mal, tô começando a ter alergia quando eu uso a massa. Ai eu tenho que mudar de emprego e só vai se a pessoa estudar. Tem uns amigos meus que quer me levar pra outras empresas, ai só vai que tem que ter estudo. Eu nem tenho mais preguiça de ir para escola não. A escola é calma, a sala de aula é boa, a gente fica tranquilo, escuta bem direitinho o que a professora fala e é bom.

João nos parece carregar uma culpa de não ter conseguido concluir seus estudos no tempo entendido como de idade apropriada para frequentar a escola. $O$ estudante tem praticamente a mesma idade da promulgação da Constituição Federal (BRASIL, 1988) que Ihe concede, assim como a todos os brasileiros, a Educação como direito e como política social 
básica. Sua narrativa representa a de muitos outros adultos que, por quaisquer motivos, foram "expulsos da escola" que frequentavam, quando mais jovens, encaminhando-os para estarem, atualmente, nas turmas de EJA.

Alguns desses estudantes que foram e ainda são expulsos, sequer voltam à escola. Outros, assim como João, retornam aos bancos escolares por diversas razões, que são às vezes resumidas como: “Agora tá fazendo falta pra mim”. Esta fala não é isolada de um contexto. Entendemos que a escola está fazendo falta para João, por conta que este espaço é ○ único projetado por ele onde pode ter "estudo" para conseguir um emprego melhor. Mas também é um espaço onde ele constrói laços de amizades que o ajuda a estar frequentando à EJA. Lembramos que, mesmo não conseguindo entender a Matemática da escola, João informou que "às vezes eu pegava de uma amiga que me ajudava, gente muito boa. Mas só que às vezes tava certo, outras tava errado, aí a professora me ajudava”.

Ao propor uma educação libertadora, Freire (2005) salienta a necessidade antes do sentimento de comunhão entre os sujeitos aprendentes que, envolvidos nos espaços educativos, possam juntos buscar por transformar suas realidades de exploração e opressão. Percebemos que esse sentimento se encaminha na turma de João, onde ele conta com a ajuda da amiga e da professora. Ainda que essa "ajuda" esteja direcionada às atividades relacionadas aos conteúdos matemáticos, para João, no momento presente, aprender estes conteúdos pode contribuir para que futuramente ele consiga um melhor emprego.

Encontramos, nessa continuidade do diálogo apresentado, o entendimento freireano de que o homem é um ser inconcluso. Quando João informa que agora, no presente, seu estar na EJA pode the render "aprender coisas que tinha que aprender no passado, como também a Matemática", projeta para seu futuro a conquista de "um emprego melhor pra mim", ele reconhece seu estar no mundo como em busca permanente de ser mais (FREIRE, 2005). Além disso, João desenvolve a autoconsciência crítica de que ele mesmo é o seu ponto de partida para ser mais, mas que a transformação depende da comunhão de pensamento e da inteireza das relações com outros sujeitos em sua mesma situação.

Segundo Mileto (2009), a ação ajudar uns os outros, construída pelos os estudantes da EJA, retratam exemplos de cooperação e solidariedade, marcas frequentem na própria modalidade. De acordo com o referido autor, essas relações de ajuda, cooperação e solidariedade, constituem "importantes redes de relações" que, dente outros fatores, 
Palavra falada, diálogo e escuta freireanos: contribuições à compreensão dos saberes...

fornecem "um suporte mútuo para a efetivação de processos de permanência" (MILETO, 2009, p. 170) dos estudantes na escola. Reconhecemos que as redes de relações construídas pelos estudantes da EJA, no âmbito da sala de aula, são importantes fatores que influenciam sobre suas permanências na escola. Complementamos que a escuta atenta dos saberes destes estudantes, por partes dos professores, poderia encaminhar práticas curriculares mais próximas das especificidades de cada um deles, dos contextos da EJA e da comunidade educativa.

É possível que, assim como João, outros estudantes gostem de frequentar a EJA, não só porque os conteúdos escolares lhes fazem falta, mas a escola faz falta de diferentes maneiras: é o acolhimento, as afetividades e as relações construídas nesse espaço que também os fazem nela estarem frequentes, é o pertencimento à escola (LEMOS; CARMO, 2016). Entretanto, o que temos atualmente no Brasil, é o encaminhamento de fechamento de escolas de EJA e de turmas dessa modalidade em diversas regiões, inclusive, o sistema municipal que João estudou em 2018, encontra-se nesta mesma direção. Essas circunstâncias políticas têm encaminhado não só um desaparecimento da modalidade, uma invisibilidade institucional ou curricular (CAVALCANTE, 2019), mas um silenciamento mesmo de tentativa de calar as potencialidades que os espaços educativos e a EJA têm para formar cidadãos, sujeitos trabalhadores, em sujeitos críticos de suas realidades.

Nesse sentido, frisamos a relevância dos professores, em especial os que lecionam na EJA, em estarem atentos, nas salas de aulas, para escutar de onde vem e como são construídos os saberes dos jovens, adultos e idosos, e de que forma os saberes escolares podem ser deles aproximados. A existência desses sujeitos requer essa sensibilidade de enxergá-los como sujeitos humanos que têm histórias de vida, e suas realidades concretas. Como sinaliza Freire (2005), essa existência mesma, porque humana, não é muda, nem pode ser silenciada, oprimida. Entendemos que ela precisa ser potencializada.

“Quem não sabe ler, meu filho, faz o quê na vida?’: a leitura de mundo na narrativa de dona Anita

Nesta seção destacamos como o diálogo e a escuta dos jovens, adultos e idosos, estudantes da EJA, em atividades didático-pedagógicas, pode ser um caminho à compreensão dos seus saberes e das suas histórias de vida. Nela apresentamos resultados de uma atividade autobiográfica construída

Olhar de professor, Ponta Grossa, v. 24, p. I-22, e-16666.038, 2021.

Disponível em <https://revistas2.uepg.br/index.php/olhardeprofessor> 
no âmbito de uma turma das séries iniciais do Ensino Fundamental da EJA de uma escola pública municipal, localizada no estado do Rio de Janeiro, durante o ano 2019.

A atividade levou o título de "Estrela da Vida". Com ela objetivou-se compreender quem são os estudantes da EJA daquela escola pública e, diante disso, entender como os saberes são construídos em suas vivências. A mesma focou na construção de um desenho em formato de estrela, onde, em suas pontas, os estudantes poderiam informar alguns aspectos de suas memórias. A construção dessa atividade desencadeou a captação das narrativas dos estudantes que fizeram parte de uma pesquisa que buscou compreender a motivação dos estudantes idosos em buscar formação escolar (DIAS, 2020). Destacamos a seguir, a estrela da vida de Dona Anita.

Figura 1: Estrela da Vida de Dona Anita.

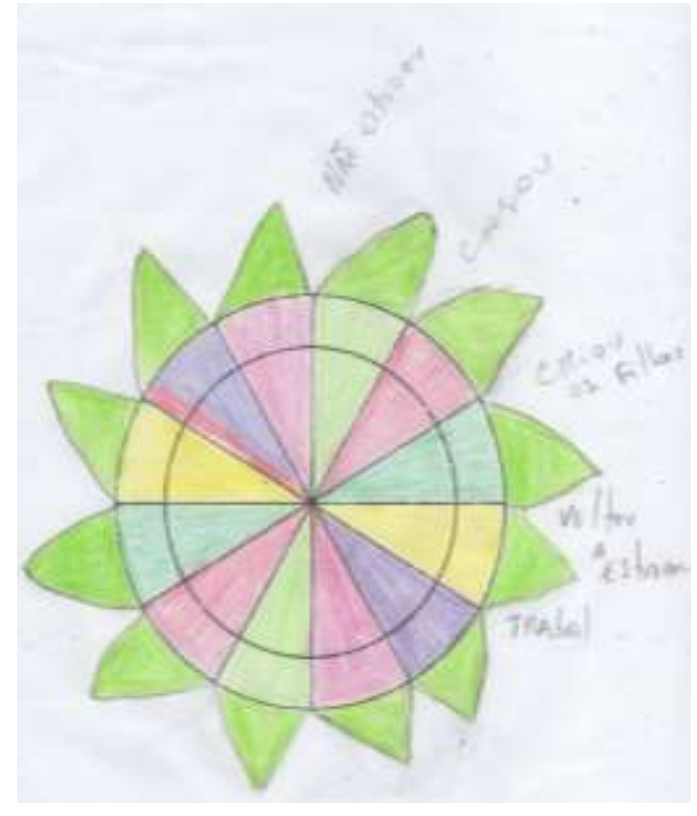

Fonte: Dias, 2020.

Dona Anita é uma senhora idosa, tem 74 anos, apresenta-se como branca, católica e viúva. É mãe de cinco filhos adultos, mas vive sozinha em casa própria, próximo da escola em que estuda. Atualmente encontra-se aposentada e sua renda mensal é inferior a um salário mínimo. No ano de 2019 esteve matriculada em uma turma da EJA no Ensino Médio, contudo, frequentava as aulas em uma turma multisseriada, das séries iniciais do Ensino Fundamental, pois estava em processo de alfabetização e sentia-se melhor recebida nesta última. Em sua estrela da vida é possível ler o percurso descrito pela estudante, para explicitar e narrar sua história, ela "não estudou”, "casou”, "criou os filhos", "voltou a estudar" e "trabal" (importância do trabalho). 
Palavra falada, diálogo e escuta freireanos: contribuições à compreensão dos saberes...

Entendemos que esse caminho de vida é um marcador de gênero, sendo trançado especialmente pelas mulheres que, em geral, chegam às turmas de EJA com motivações diferentes dos homens (FONSECA, 20I2), geralmente depois de terem criados os filhos, netos, como é o caso de Dona Anita. A proposta da atividade didático-pedagógica encaminhou o diálogo da estudante com o pesquisador. Em sua narrativa, Dona Anita fala de seu lugar de mulher que, criada em um ambiente masculinizado, teve que aceitar a abdicação de seu direito de estudar.

Pesquisador: - Na sua infância, a senhora não frequentou a escola?

Dona Anita: - Bom, quando eu era nova não dava para estudar mesmo. Porque a escola era tão longe, né? Os meninos ainda iam de cavalo, de bicicleta, né? Mas eu,...Meu pai não deixava a gente ir não. Eu e minha outra irmã não ia. De jeito nenhum. Ele não deixava. Porque era muito longe e passava ainda dentro da matinha. Aí ele falava: "Não. Vocês não vão não. É muito longe para você estudar lá". E aí nós fiquemos sem estudar, né? Igual, né? A gente não sabe nada. Aí quando foi agora, depois que eu fiquei velha, que me deu uma oportunidade de ajudar ali, eu estou ali, na escola, no Colégio Municipal. Tô ali, né? Mas como diz o ditado, né? Não aprendi muita coisa não. Ainda não, mas vou aprender, com fé em Deus. Eu tenho fé que eu vou aprender. Aí como diz o ditado, a gente depois de velha que tem oportunidade tem que aproveitar ela, né? Aproveitar ela. Porque quando é mais nova não tem oportunidade que teve agora. Quando é mais nova é só casar, criar filho, tomar conta de casa, só isso mesmo, né?

A narrativa de Dona Anita retrata um pouco da história da educação brasileira, especificamente, a parte em que obter escolarização, frequentar uma escola formal, se alçava ainda como um sonho distante da realidade de muitos. Mais distante estava esse sonho dos brasileiros de classe popular, que, assim como ela, aceitavam como natural sua condição de oprimido e, por isso, não Ihes era "merecido" estudar.

Ao nos informar que não estudou quando criança "Porque a escola era tão longe, né?", entendemos que o "longe" era não só a distância da casa de Dona Anita à escola, mas o fato de ela ser mulher a distanciava mais ainda de um dia estar na escola. "Os meninos ainda iam de cavalo, de bicicleta, né?", nos diz ela. Eles ainda iam, mesmo a escola sendo longe. Esta fala retrata o lugar que as meninas e mulheres por muito tempo foram subjugadas na sociedade brasileira. Especialmente quanto às questões de gênero que atravessam as questões educacionais no Brasil, sinalizam Gondra e Schueler (2008, p. 202) que "para as meninas das camadas populares, desde muito cedo, a aprendizagem prática das atividades cotidianas nas tarefas domésticas, na agricultura ou nos ofícios urbanos era prioritária", em detrimento da aquisição dos saberes letrados e, mais ainda, da possibilidade de ocupação de postos de trabalhos.

As ideias de uma suposta natureza feminina, alimentadas pelo que entendemos ser um conservadorismo, pronunciado no discurso de "cuidado" do homem, foram também cruciais para que Dona Anita e sua irmã não estudassem quando criança. Percebemos isso quando ela nos diz: "Meu pai

Olhar de professor, Ponta Grossa, v. 24, p. I-22, e-16666.038, 2021.

Disponível em <https://revistas2.uepg.br/index.php/olhardeprofessor> 
não deixava a gente ir não. Eu e minha outra irmã não ia. De jeito nenhum. Ele não deixava. Porque era muito longe e passava ainda dentro da matinha".

Entendemos que essas ideias são internalizadas pela estudante que, assim como muitos outros jovens, adultos e idosos que estão na EJA, projetam na perda da oportunidade, a sua explicação de não ter estudado. O sentimento de culpa de que a escola "Agora tá fazendo falta pra mim", afirmado anteriormente pelo estudante João, é aprofundado e atravessado pelas especificidades da estudante mulher, Dona Anita: “A gente depois de velha que tem oportunidade tem que aproveitar ela, né? Aproveitar ela. Porque quando é mais nova não tem oportunidade que teve agora. Quando é mais nova é só casar, criar filho, tomar conta de casa, só isso mesmo, né?".

Dona Anita toma pra si, como que natural, as situações as quais foi condicionada, desde que criança: mulher não precisa estudar, tem que primeiro criar os filhos e se responsabilizar pelos ofícios domésticos. A estudante narra uma história de vida que, mesmo sob seu olhar específico, se aproxima de histórias de outras mulheres. Dona Anita narra o seu mundo, e aquele seu estar sendo (FREIRE, 2005), quando criança, e as suas condições mesmas de ser mulher em um ambiente hostil, as possibilitaram construir estratégias de sobrevivência, ler o mundo de sua maneira peculiar.

Pesquisador: - E nesse tempo, até quando a senhora era mais jovem assim, por que a senhora não quis estudar à noite? Não tinha curso?

Dona Anita: - Aqui tinha. Toda vida teve. Lá na em cima, na escolinha de cima lá. É, mas eu trabalhava mais fora, não dava tempo. Eu não pude estudar por causa disso, né? Eu trabalhava lá nos Cavaleiros. Lá nos Cavaleiros. Aí quando eu chegava. Eu chegava as sete e pouca da noite e não dava tempo de estudar. Saia às cinco e meia da manhã todo dia e chegava às sete horas da noite. Eu vinha, pegava o ônibus até a rodoviária. Aí pegava outro ônibus que vinha, chegava aqui não dava tempo de eu estudar. Aí eu fiquei esse tempo todo só trabalhando, sem estudar, né? Trabalhando aqui, trabalhando ali. E fui levando a vida, né? E agora, de certos tempos pra cá, que eu fiquei sem trabalhar fora, né? Não tô trabalhando fora mais, né? Aí eu falei: - Ah! Vou ver se eu estudo. Aí a vizinha animou. Ai eu falei: - Vamos lá, vamos estudar. Ai eu falei: - Vou lá, vou lá me matricular então. E tô lá.

O excerto acima nos permite entender que a condição de Dona Anita estar no mundo foi encaminhada, quando em sua juventude, pela relação com atividades laborais. Antes não estudar se dava pelo fato de ela ser menina, agora (quando ela jovem), se dava também pela necessidade de ter que trabalhar. Onde ela morava "Toda vida teve" escola, mas ela "trabalhava mais fora, não dava tempo" de estudar. Realidade que só seria modificada quando em sua velhice.

O percurso entre "cinco e meia" da manhã até "sete horas da noite", explicitado pela estudante, nos permite aproximar as reflexões propostas por Arroyo (2017, p. 2I), quando este, sinalizando as especificidades dos jovens, adultos e idosos, referem-se a estes como "passageiros da noite", que têm escolhas "não tão livres", entre estas, a de trabalhar e estudar ao mesmo tempo, ou apenas trabalhar, caso tenham que optar entre os dois. Assim como Dona Anita foi por muito tempo, 
Palavra falada, diálogo e escuta freireanos: contribuições à compreensão dos saberes...

são eles os sujeitos humanos concretos que, durante o dia estão no "duro", no trabalho, pegam ônibus, atravessam as cidades levando consigo suas histórias de vida. À noite, eles são a escola. Constroem os contextos educacionais e os tensionam com suas realidades, com as imagens quebradas (ARROYO, 2014) com que foram sendo construídos e construindo-se desde tenra infância.

Reconhecer-se no mundo como sujeitos estando nele e, por isso, capazes de modificá-lo, faz os homens, e incluímos, por inferência de gênero, as mulheres, tomarem consciência crítica de suas realidades. Segundo Freire (2005), a criticidade com que estes sujeitos compreendem o mundo e os seus estar nele, os possibilitam tomarem a si mesmo como ponto central de suas decisões políticas. Isso seria um primeiro encaminhamento à efetivação da construção de uma educação com sentido de ação libertadora. $O$ referido intelectual destaca que os sujeitos

[...] desafiados pela dramaticidade da hora atual, se propõem, a si mesmos, como problema. Descobrem que pouco sabem de si, de seu "posto no cosmos", e se inquietam por saber mais. Estará, aliás, no reconhecimento do seu pouco saber de si uma das razões desta procura. Ao instalar-se na quase, senão trágica descoberta do seu pouco saber de si, se fazem problema a eles mesmos. Indagam. Respondem, e suas respostas os levam a novas perguntas (FREIRE, 2005, p. 3I).

Entendemos que os sujeitos proporem a si mesmo como problema, é sinalizado por Freire (2005) no sentido de que os homens e mulheres, porque humanos, são dotados de uma consciência. Ao compreenderem a si mesmo enquanto inconclusos no mundo, e às suas realidades, estes podem desenvolver suas autoconsciências críticas e, então, unidos, poderão rebelarem-se das situações de opressão.

Na sequência do diálogo entre pesquisador e Dona Anita, é possível entender que a condição de ela não saber ler os códigos da Língua Portuguesa, da palavra escrita, não limitaram seu estar no mundo.

Pesquisador:- $O$ fato de não saber ler atrapalhou ou dificultou a sua vida?

Dona Anita: - Era muito difícil a minha vida de primeiro. É muito difícil porque eu não sabia ler, né? Não sabia ler e pra pegar o ônibus era um sacrifício, né? Mas aí depois Deus ajuda a gente, que agora eu já estou conhecendo, já. Já conheço já as letras do ônibus, já sei para onde vai. Se vai pra ali, vai pra cá. Eu já sei. Já sei mais ou menos. Contar dinheiro também já sei. Já sabia já. Contar dinheiro eu já sabia já. Muito fácil, né? Contar dinheiro, né? Aí depois, eu falei assim: - Ah! Tem que dar um jeito na minha vida. Estudar um pouco cadinho. Que é tão ruim não aprender as coisas, né? Serviço de casa a gente sabe fazer, né? Passar roupa a gente sabe passar, lavar. Mas o negócio é a leitura que faz muita falta. Faz muita falta a leitura. A leitura pra gente faz muita falta. Quem não sabe ler, meu filho, faz o quê na vida? Só trabalha, né? Aí depois eu falei assim: - Ah não, vou estudar então. Aí a vizinha falava: - "Vamos estudar. Eu tô estudando. Vamos?" Aí eu falei: - Ah, então eu vou. É bom. Sabe o que também? A gente diverte a mente. Conversa com um lá, conversa com outro, né? Aí panha amizade com o pessoal. Muito bom. Eu nem de casa eu quase saia, é só trabalhar, só trabalhar. Aí eu falei: - Não! Tenho que dar um jeito na minha vida. Aí foi para lá estudar.

Olhar de professor, Ponta Grossa, v. 24, p. I-22, e-16666.038, 2021.

Disponível em <https://revistas2.uepg.br/index.php/olhardeprofessor> 
A "vida de primeiro" de Dona Anita era difícil, se tornava mais difícil, reafirmamos, pelo fato de ser mulher e não ter estudado. Entretanto, com "sacrifício", ela foi levando-se na vida, construindose nela e modificando-a. Informa-nos a estudante: "Não sabia ler e pra pegar o ônibus era um sacrifício, né? Mas aí depois Deus ajuda a gente, que agora eu já estou conhecendo, já”. Nesta fala, entendemos que, ao evocar uma figura divina, ela toma para si o sentimento de culpa por não ter aprendido os saberes escolares, agora, o de não saber ler.

As leituras de produções de narrativas de estudantes da EJA, em especial dos idosos, nos permitem afirmar ser recorrente a evocação de uma figura divina, no sentido de eles devotarem ou agradecerem por estarem na escola ou por ter aprendido algo. Com Dona Anita não é diferente. Segundo Freitas (2013), os estudantes mais idosos, em especial as mulheres, retornam aos bancos escolares, motivadas, em geral, pela possibilidade de aprenderem a ler a bíblia. Enfatizamos essa leitura da palavra escrita, tendo em vista que a leitura do mundo já é, por si só, construída nas experiências desses sujeitos, conforme assinala Freire (2005).

É na experiência na lida de pegar os ônibus, quando da labuta diária, que Dona Anita vai desenvolvendo sua leitura da palavra escrita: "Já conheço já as letras do ônibus, já sei para onde vai. Se vai pra ali, vai pra cá. Eu já sei. Já sei mais ou menos”. Assim, o sacrifício vai tomando outra dimensão, a da gratidão em estar aprendendo a ler, que é por ela empregada a Deus. Os saberes de Dona Anita foram sendo construídos no seu percurso de ser mulher, e diante das condições que lhes são ainda naturais: "Que é tão ruim não aprender as coisas, né? Serviço de casa a gente sabe fazer, né? Passar roupa a gente sabe passar, lavar. Mas o negócio é a leitura que faz muita falta. Faz muita falta a leitura".

Dentro de seus limites, Dona Anita infere-nos haver distinção, sob sua perspectiva, sobre o que é "aprender as coisas". Parece-nos que para ela existe o aprender, natural mesmo do ser mulher, estes seriam os serviços de casa, e o aprender da escola, que seria apreender a leitura da palavra escrita, pois as contas ela já sabe: "Contar dinheiro também já sei. Já sabia já. Contar dinheiro eu já sabia já. Muito fácil, né? Contar dinheiro, né?". O "dinheiro" que acompanha os deslocamentos de Dona Anita no trânsito de pegar os ônibus para o trabalho, está em seu próprio salário, e que lhe parece também natural aprender a contá-lo.

Entendemos que o excerto dessa fala de Dona Anita comprova que o seu estar no mundo não foi limitado por ela não saber ler as palavras escritas ou realizar contas da Matemática da escola. Dona Anita, como um sujeito mulher alfabetizada politicamente, moveu-se no mundo, construiu-se nele e ainda busca o seu ser mais (FREIRE, 2005). Sua narrativa de senhora de idade que, reconhecendo-se como "velha", é como a de muitas outras mulheres e, em parte, de outros homens que, assim como ela, são trabalhadores e buscam nas turmas de EJA os seus reconhecimentos sociais. 
Palavra falada, diálogo e escuta freireanos: contribuições à compreensão dos saberes...

É uma história trançada por fios de movimentos de vitórias, de derrotas, encontros e desencontros consigo mesmo e com o mundo. Chega um momento em que basta um "Não! Tenho que dar um jeito na minha vida", no sentido de Dona Anita, para que as situações de opressão possam ser reconhecidas, e combatidas. Trata-se, segundo Freire (2005), da superação da acomodação na mesmice, na consciência ingênua, no ajustamento passivo, em busca de sua própria libertação.

A narrativa de Dona Anita, iniciada em uma atividade didático-pedagógica em sala de aula, é uma amostra de que os cotidianos dos espaços educativos e as salas de aula da EJA são potenciais espaços de construção constante de práticas curriculares, sentidos de currículos, que podem ser encaminhados a partir das experiências dos sujeitos que os compõem. Reforçamos que a escuta atenta da fala da estudante, mediada pelo diálogo horizontal com o pesquisador, foi essencial para que a mesma se dispusesse narrar sua vida sem medo de ser taxada.

\section{CONSIDERAÇÕES FINAIS}

Neste artigo buscamos discutir sobre como a escuta atenta dos saberes dos jovens, adultos e idosos podem contribuir para os professores construírem práticas curriculares mais próximas das realidades educandos e da modalidade EJA. Para isso, lançamos luz sobre os entendimentos de escuta atenta, palavra falada e diálogo, na perspectiva freireana.

Ao enveredarmos no percurso de construção de uma educação proposta por Paulo Freire sob o viés democrático, crítico e libertador, compreendemos encontros de ideias do que hoje se pensa como ideal de educação voltada para pessoas jovens, adultas e idosas. Dentre estes encontros, destacamos os espaços educativos como possibilitadores de conscientização crítica dos estudantes, de modo que, em comunhão, estes possam se rebelarem contra as situações de opressões em que se encontram. Encaminhamos, assim, a compreensão de que os princípios do pensamento de Paulo Freire se mantêm atuais quando se discute educação no Brasil, em especial, a educação de jovens, adultos e idosos.

A contribuição às práticas curriculares é aqui apresentada por meio de narrativas dos estudantes João e Dona Anita. Estes, em encontros com pesquisadores, discorrem às suas maneiras, sobre suas vidas, as relações com o mundo e as relações estabelecidas em suas vivências. Estas narrativas, em nossas perspectivas, retratam como os saberes matemáticos e de leitura são construídos nas experiências do trabalho e dos estar no mundo desses dois estudantes.

Na narrativa de João identificamos a existência de pelos menos duas matemáticas: a construída em sua vida profissional, utilizada por ele para estabelecer valores aos serviços de pintura automotiva ao qual é contratado; e a matemática da escola, a qual ele se refere como sendo da "matéria" que "a professora passa uma prova pra saber né, quem tá bom, quem aprendeu". Para João, esta última seria 
“normal”, talvez porque sendo ela "passada" pela professora e estando no espaço próprio de ensino, fosse natural vivenciá-la enquanto "matéria" escolar. O "normal" também se refere ao modo como a sua professora ensinava e depois cobrava os conteúdos em uma prova, perfazendo, assim, um comum percurso das práticas curriculares matemáticas de muitos professores.

A narrativa de Dona Anita se encaminha em explicar as razões de ela não ter frequentado a escola quando criança, e ter buscado estudar apenas "depois de velha”. Dona Anita é uma estudante matriculada na EJA do Ensino Médio, contudo, ainda encontra-se em processo de alfabetização, o que, somado às formas como ela foi recebida em uma turma de Alfabetização, a fez frequentar as aulas nesta. Percebemos que a história de vida da referida estudante é marcada, sobretudo, pela sua condição de ser mulher e viver em um ambiente masculinizado que, entre outros fatores, levaram a abdicar de seu direito de estudar.

Ainda que cerceada desse direito, Dona Anita construiu seu estar no mundo atravessado com as questões de gênero, afirmando seu lugar nos espaços tidos como masculinos. A condição de não leitora das palavras escritas não a impediu de identificar os ônibus que deveria pegar para chegar ao seu trabalho, ou mesmo de contar dinheiro que, inclusive, ela considera muito fácil. $O$ ir e vir, no trânsito entre sua casa e o trabalho, fez Dona Anita compreender o mundo e conhecer as letras, antes mesmo de conhecer a escola. Em sua narrativa, ela reconhece que ao frequentar a EJA, melhorou esse conhecimento e, então, foi conseguindo alfabetizar-se.

A escuta das narrativas de João e Dona Anita, reforçam a perspectiva freireana de que os jovens, adultos e idosos, não chegam à escola como uma caixa vazia, a ser preenchida com conteúdos escolares, transmitidos pelo professor. São eles, sujeito politicamente alfabetizados e possuidores de saberes que são os seus próprios estar no mundo.

A construção dos estudos aqui apresentados, além de nos possibilitar conhecer quem são os estudantes da EJA, permitiu-nos compreender o quanto a escuta atenta de suas narrativas podem contribuir para pensarmos os currículos, os conteúdos escolares, até mesmo as políticas educacionais, sob os pontos de vistas dos estudantes e dos professores da EJA. Reafirmamos que os professores da EJA, reconhecendo-se a si mesmos e os estudantes como sujeitos dotados de uma consciência que pode ser construída em um sentido crítico, poderia incorporar as experiências destes em suas práticas curriculares.

Em linhas gerais, as narrativas de João e Dona Anita nos dão forças para, enquanto educadores, continuarmos a luta em defesa da EJA e dos direitos dos jovens, adultos, e idosos. Luta esta tão cara a Paulo Freire, e que ele defendeu em toda sua trajetória, com o objetivo de proporcionar uma educação realmente pública, democrática e de qualidade para todos os brasileiros, em especial, aos oprimidos da classe trabalhadora. 
Palavra falada, diálogo e escuta freireanos: contribuições à compreensão dos saberes...

\section{Referências}

AQUINO, J. G. Erro e Fracasso na Escola: alternativas teóricas e práticas. São Paulo: Summus, 1997.

BERNARDO, J. Economia dos Conflitos Sociais. 2. ed. São Paulo: Expressão Popular, 2009.

Recebido em: I5 de agosto de 2020.

Versão corrigida recebida em: 10 de março de 202I.

Aceito em: 10 de março de 2021 .

Publicado online em: 30 de abril de 2021 .

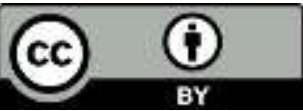

